\title{
PRODUCTION AND QUALITY OF SILAGES PEARL MILLET AND PAIAGUAS PALISADEGRASS IN MONOCROPPING AND INTERCROPPING IN DIFFERENT FORAGE SYSTEMS
}

\author{
PRODUÇÃO E QUALIDADE DA SILAGEM DE MILHETO E CAPIM-PAIAGUÁS EM \\ MONOCULTUVO E CONSORCIADO EM DIFERENTES SISTEMAS FORRAGEIROS
}

\section{Raoni Ribeiro Guedes Fonseca COSTA ${ }^{1}$; Kátia Aparecida de Pinho COSTA ${ }^{2}$; Wender Ferreira de Souza ${ }^{2}$; Patrícia Soares EPIFANIO ${ }^{3}$; Charles Barbosa SANTOS ${ }^{3}$; Jessika Torres da SILVA ${ }^{3}$; Suelen Soares OLIVEIRA ${ }^{3}$}

1. State University of Goiás (Universidade Estadual de Goiás - UEG), Quirinópolis, GO, Brazil; 2. Professors, Postgraduate Program in Agricultural Sciences/Agronomy and Animal Science, Federal Institute of Goiás, (Instituto Federal Goiano - IF Goiano) Rio Verde, GO, Brazil. Katia.costa@ifgoiano.edu.br; 3Students of the Postgraduate Program in Agricultural Sciences - Agronomy and Animal Science, Federal Institute of Goiás (Instituto Federal Goiano - IF Goiano); Rio Verde, GO, Brazil.

\begin{abstract}
With the arrival of new early genotypes and high nutritive value and productive potential, millet has been gaining prominence in recent years for the production of silage, and it promises lower costs of production. Thus, the consortium of millet with tropical forages can increase the production of silage, providing more food to be used in the offseason, where there is low availability of forage. The objective of this study was to evaluate the dry mass production, fermentative characteristics and chemical-bromatological of pearl millet silage and Paiaguas palisadegrass in monocropping and intercropping in different forage systems in the second cropping season. The experimental design consisted of randomized blocks with four replicates. The treatments consisted of silage of the following forage systems: monocropped pearl millet, monocropped Paiaguas palisadegrass, pearl millet intercropped in rows with Paiaguas palisadegrass, pearl millet intercropped inter-row with Paiaguas palisadegrass, and pearl millet oversown and intercropped with Paiaguas palisadegrass (totaling 20 experimental plots). The consortium of pearl millet with Paiaguas palisadegrass contributed to raise the dry matter contents of the silages, except in the system using the overgrowth. Pearl millet silages monocropped and intercropped with Paiaguas palisadegrass presented reductions in $\mathrm{pH}$ and ammoniacal nitrogen values as well as favor lactic fermentation. Pearl millet monocropped and intercropped silage exhibited better fermentative and bromatological characteristics than silage obtained from monocropped Paiaguas palisadegrass. Therefore, creating silage from intercropped forages provides an interesting supplemental roughage option that can be used during the offseason for animal feeding.
\end{abstract}

KEYWORDS: Brachiaria brizantha. Fermentative characteristics. Bromatological composition. Pennisetum glaucum (L.) R. Br.

\section{INTRODUCTION}

Silages have been used as efficient solutions in low forage production periods to provide highquality ruminant feed. Among the available or recommended crops for ensiling, grasses of the genus Brachiaria have attracted interest and have been widely used with positive results (COSTA et al., 2011a; EPIFANIO et al., 2014; PERIM et al., 2014). In addition, interest in producing silage with this species partially results from advances in ensiling techniques and the emergence of specific harvesters for small or medium-sized forages.

Recently, the Beef Cattle division of the Brazilian Corporation of Agricultural Research (Empresa Brasileira de Pesquisa Agropecuária [Embrapa] Gado de Corte) released a new cultivar, Brachiaria brizantha (BRB Paiaguas). This cultivar is an important alternative for diversification in areas currently planted with Marandu palisadegrass and has significant advantages for use in croplivestock integration systems. The main advantage of BRS Paiaguas is observed during the dry season, when an increased accumulation of forage with higher nutritional value occurs and the annual productivity increases (EMBRAPA GADO De CORTE, 2014).

Grass silages display some advantages, including high annual production per area, perennial growth, low risk of loss, and large harvesting flexibility. However, these silages also display some unfavorable features, including low soluble carbohydrate levels, which are required for proper fermentation; low dry matter content at the time of cutting; high buffering capacity; and lower energy values compared with maize, sorghum and pearl millet (PERIM et al., 2014).

Silage from pearl millet intercropped with Brachiaria represents an alternative for minimizing these problems. Pearl millet has mainly been 
explored in offseason crops due to its agronomic characteristics of high drought resistance, wide adaptation, and high dry matter production. Coupled with its rapid growth, this species deserves attention for producing high-quality silage that can be used to produce quantities of supplementary feed that are satisfactory during this time of year (GUIMARÃES JR. et al., 2008). In addition, pearl millet has gained importance from the availability of earlier and higher-yielding genotypes with lower silage production costs, thanks to genetic improvements (COSTA et al., 2012).

However, studies that evaluate silage production and quality in intercropping systems are scarce. Regarding the new Brachiaria brizantha cultivar (BRS Paiaguas) and the new pearl millet hybrid, it is important to generate additional information regarding the methods used for sowing these crops in simultaneous cultures to produce higher-quality silage. This study aimed to evaluate the dry mass production, fermentative characteristics and chemical composition of pearl millet silage and Paiaguas palisadegrass in monocropping and intercropping in different forage systems in the second cropping season.

\section{MATERIAL AND METHODS}

This experiment was conducted in the field $\left(17^{\circ} 48^{\prime} \mathrm{S} ; 50^{\circ} 55^{\prime} \mathrm{W}\right.$; and $748 \mathrm{~m}$ altitude) in the municipality of Rio Verde, Goiás, Brazil, during the 2014 offseason on a dystroferric Red Latosol. During the experiment, total rainfall and mean temperature data were $540 \mathrm{~mm}$ and $23^{\circ} \mathrm{C}$, respectively.

Before planting, soil samples were collected from the $0-20 \mathrm{~cm}$ layer to assess the physical and chemical characteristics of the experimental area. Overall, the following values were obtained: clay, $600 \mathrm{~g} \mathrm{~kg}^{-1}$; silt, $140 \mathrm{~g} \mathrm{~kg}^{-1}$; sand, $270 \mathrm{~g} \mathrm{~kg}^{-1}$; $\mathrm{pH}$ in $\mathrm{CaCl}_{2}, 6.02 \mathrm{cmol}_{\mathrm{c}} \mathrm{dm}^{-3} ; \mathrm{Ca}, 3.50 \mathrm{cmol}_{\mathrm{c}} \mathrm{dm}^{-3} ; \mathrm{Mg}$, $1.43 \mathrm{cmol}_{\mathrm{c}} \mathrm{dm}^{-3} ; \mathrm{Al}, 0.05 \mathrm{cmol}_{\mathrm{c}} \mathrm{dm}^{-3} ; \mathrm{Al}+\mathrm{H}, 5.9$ $\mathrm{cmol}_{\mathrm{c}} \mathrm{dm}^{-3} ; \mathrm{K}, 0.35 \mathrm{cmol}_{\mathrm{c}} \mathrm{dm}^{-3}$; cation exchange capacity (CEC), $11.14 \mathrm{cmol}_{\mathrm{c}} \mathrm{dm}^{-3} ; \mathrm{P}, 2.29 \mathrm{mg} \mathrm{dm}^{-3}$; $\mathrm{Cu}, 3.5 \mathrm{mg} \mathrm{dm}^{-3}$; $\mathrm{Zn}, 5.1 \mathrm{mg} \mathrm{dm}^{-3} ; \mathrm{Fe}, 34.1 \mathrm{mg} \mathrm{dm}^{-3}$; and organic matter $(\mathrm{OM}), 37.06 \mathrm{~g} \mathrm{dm}^{-3}$.

The area was prepared by desiccating weeds using the herbicide Transorb $\left(3.5 \mathrm{~L} \mathrm{ha}^{-1}\right)$ at a spray volume of $150 \mathrm{~L} \mathrm{ha}^{-1}$. Thirty days after desiccation, harrowing (using a disk harrow) and additional harrowing were performed to eliminate any weeds not controlled by the herbicide. One week before implementing the experiment, harrowing was conducted again, and the field was sown in furrows using a seeder with an inter-row spacing of $0.50 \mathrm{~m}$.
The experimental design consisted of randomized blocks with four replicates. The treatments consisted of silage the following forage systems: monocropped pearl millet, monocropped Paiaguas palisadegrass, pearl millet intercropped in rows with Paiaguas palisadegrass, pearl millet intercropped inter-row with Paiaguas palisadegrass, and pearl millet oversown and intercropped with Paiaguas palisadegrass (totaling 20 experimental plots). The pearl millet hybrid used was ADR 8010 (medium-sized and dual purpose).

Sowing was performed on February 12, 2014 , with $240 \mathrm{~kg} \mathrm{ha}^{-1} \mathrm{P}_{2} \mathrm{O}_{5}$ and $20 \mathrm{~kg} \mathrm{ha}^{-1}$ FTE BR 12. Monocropped and intercropped pearl millet were sown at a depth of $3 \mathrm{~cm}$. Paiaguas palisadegrass was sown at a depth of $6 \mathrm{~cm}$ in the inrow intercropping system and $25 \mathrm{~cm}$ from the pearl millet rows in the inter-row intercropping system. In the oversown system, Paiaguas palisadegrass was sown 15 days after sowing pearl millet in the interrow at $25 \mathrm{~cm}$. Fourteen seeds per meter of pearl millet and $5 \mathrm{~kg}$ of pure viable seeds per hectare of forage species were used. The plots consisted of eight 3.0-m-long rows in all forage systems. The useful area was obtained by only considering the four central rows and eliminating $0.5 \mathrm{~m}$ from each end. Two applications were performed, at 30 and 50 days after emergence (DAE), each with $60 \mathrm{~kg} \mathrm{ha}^{-1} \mathrm{~N}$ in the form of urea and $40 \mathrm{~kg} \mathrm{ha}^{-1} \mathrm{~K}_{2} \mathrm{O}$ in the form of potassium chloride, as topdressing fertilizers.

The forages were harvested at $65 \mathrm{DAE}$ for ensiling using a backpack mower. To evaluate the DM yield and proportion of silage material, the samples were collected in one square meter. Whole pearl millet and Paiaguas palisadegrass plants were harvested $20 \mathrm{~cm}$ above the soil surface. Subsequently, the pearl millet and Paiaguas palisadegrass were weighed, and their proportions in the forage systems were determined. Next, a portion of the material was dried in an oven at $55^{\circ} \mathrm{C}$ until a constant weight was achieved to obtain the dry weight, which was converted to $\mathrm{kg} \mathrm{ha}^{-1}$.

The material was chopped to 10 to $30 \mathrm{~mm}$ by using a stationary forage harvester (model EM9F3B, Nogueira). Next, the material was stored in experimental PVC silos measuring $10 \mathrm{~cm}$ in diameter and $40 \mathrm{~cm}$ in length. The material was compacted using an iron pendulum that was closed with PVC caps and sealed with tape to prevent the entrance of air. The experimental silos were allocated in a covered area at room temperature.

After 50 days of fermentation, the silos were opened. The material at the top and bottom of each silo was discarded, and the central portion was stirred and placed in plastic trays. After opening the 
silos, a portion of the fresh silage was separated to determine the $\mathrm{pH}$, titratable acidity (TA) (by the method of Silva and Queiroz (2002)), and buffering capacity (BC) (by the method of Playne and McDonald (1966)).

Next, a sample of silage was removed and divided into two parts. The first part was placed in plastic bags and frozen. To determine the ammoniacal nitrogen $\left(\mathrm{N}-\mathrm{NH}_{3} \mathrm{~g} \mathrm{~kg}^{-1} \mathrm{~N}\right)$ content, the samples were defrosted to extract juice. The organic acid levels were determined using a Shimadzu, SPD-10A VP high-performance liquid chromatographer (HPLC) coupled with an ultraviolet (UV) detector with a wavelength of 210 $\mathrm{nm}$ according to the method described by Kung Jr. (1996).

The other part of the silage, which weighs approximately $1 \mathrm{~kg}$, was dried in a forced-air oven at $55^{\circ} \mathrm{C}$ for 72 hours. Subsequently, the silage was ground using a Willey knife mill with a $1 \mathrm{~mm}$ diameter sieve and stored in plastic containers.
Bromatological analyses were performed to determine the dry matter (DM) (Method CA G003/1), crude protein (CP) (Method N-001/1), neutral detergent fiber (NDF) (Method CA F002/1), acid detergent fiber (ADF) (Method CA F004/1), mineral material (MM) (Method CA M001/1), and ether extract (EE) (Method CA G004/1) according to INCT methods reported by Detmann et al. (2012). The total digestible nutrient (TDN) contents were estimated using the following equation proposed by Chandler (1990): TDN = 105.2 - 0.68 (NDF).

The in vitro dry matter digestibility (IVDMD) was assessed using the method described by Tilley and Terry (1963) and was adapted to the artificial rumen developed by ANKON® using the "Daisy incubator" device from Ankom Technology (in vitro true digestibility- IVTD).

Before ensiling, chemical-bromatological analysis of the forages was performed according to the methods described above (Table 1).

Table 1. Chemical-bromatological composition of pearl millet and Paiaguas palisadegrass monocropped and intercropped in different forage system.

\begin{tabular}{lccccc}
\hline Composition & $\begin{array}{c}\text { Monocropped } \\
\text { pearl millet }\end{array}$ & $\begin{array}{c}\text { Monocropped } \\
\text { Paiaguas }\end{array}$ & $\begin{array}{c}\text { Row pearl } \\
\text { millet } \mathbf{x} \\
\text { Paiaguas }\end{array}$ & $\begin{array}{c}\text { Inter-row } \\
\text { pearl millet } \mathbf{x} \\
\text { Paiaguas }\end{array}$ & $\begin{array}{c}\text { Oversown } \\
\text { pearl millet } \mathbf{x} \\
\text { Paiaguas }\end{array}$ \\
\hline $\mathrm{DM}\left(\mathrm{g} \mathrm{kg}^{-1} \mathrm{DM}\right)$ & 314 & 260 & 297 & 285 & 304 \\
$\mathrm{BC}\left(\mathrm{Emg} 100 \mathrm{~g}^{-1}\right)$ & 225 & 443 & 364 & 342 & 335 \\
$\mathrm{CP}\left(\mathrm{g} \mathrm{kg}^{-1} \mathrm{DM}\right)$ & 149 & 126 & 128 & 125 & 132 \\
$\mathrm{NDF}\left(\mathrm{g} \mathrm{kg}^{-1} \mathrm{DM}\right)$ & 545 & 701 & 608 & 615 & 597 \\
$\mathrm{ADF}\left(\mathrm{g} \mathrm{kg}^{-1} \mathrm{DM}\right)$ & 308 & 418 & 365 & 372 & 325 \\
$\mathrm{EE}\left(\mathrm{g} \mathrm{kg}^{-1} \mathrm{DM}\right)$ & 48 & 21 & 32 & 30 & 38 \\
$\mathrm{MM}\left(\mathrm{g} \mathrm{kg}^{-1} \mathrm{DM}\right)$ & 20 & 39 & 28 & 28 & 23 \\
$\mathrm{TDN}\left(\mathrm{g} \mathrm{kg}^{-1} \mathrm{DM}\right)$ & 695 & 542 & 615 & 634 & 675 \\
$\mathrm{IVDMD}\left(\mathrm{g} \mathrm{kg}^{-1} \mathrm{DM}\right)$ & 692 & 536 & 661 & 658 & 679
\end{tabular}

DM: dry matter; BC: buffering capacity; CP: crude protein; NDF: neutral detergent fiber; ADF: acid detergent fiber; EE: ether extract; MM: mineral material; TDN: total digestible nutrient; IVDMD: in vitro dry matter digestibility

The data were subjected to an analysis of variance (ANOVA), using the statistical program SISVAR 4.6 (Ferreira, 2011), and the means were compared using Tukey's test with an error probability of $5 \%$.

\section{RESULTS AND DISCUSSION}

The DM yield for ensiling was influenced $(\mathrm{P}<0.05)$ by the forage systems. The lowest yield was obtained in the monocropped Paiaguas palisadegrass, which differed from the monocropped and intercropped pearl millet. The highest yield was observed in the row and inter-row intercropping systems and showed an increase of $25.0 \%$ and $18.3 \%$, respectively, compared with the monocropped pearl millet. Therefore, the importance of the crop-livestock integration system for increasing DM yield for ensiling should be considered. 
Table 2. The dry matter (DM) yield and the proportions of the silage materials from the different forage system.

\begin{tabular}{lccc}
\hline Forage systems & $\begin{array}{c}\text { DM yield } \\
\left(\mathrm{t} \mathrm{ha}^{-1}\right)\end{array}$ & $\begin{array}{c}\text { Pearl millet } \\
\text { proportion }(\%)\end{array}$ & $\begin{array}{c}\text { Paiaguas } \\
\text { proportion }(\%)\end{array}$ \\
\hline Monocropped pearl millet & $18.321 \mathrm{~b}$ & 100 & 0 \\
Monocropped Paiaguas & $5.962 \mathrm{c}$ & 0 & 100 \\
Row pearl millet x Paiaguas & $22.907 \mathrm{a}$ & 78.38 & 21.62 \\
Inter-row pearl millet x Paiaguas & $21.689 \mathrm{a}$ & 83.05 & 16.95 \\
Oversown pearl millet x Paiaguas & $18.464 \mathrm{~b}$ & 95.43 & 4.57 \\
CV $(\%)$ & & 16.14 & \\
\hline
\end{tabular}

Means followed by different letters differ according to Tukey's test at a probability level of 5\%.

Regarding the proportion of the ensilage material, the silage of the oversown system showed lower amount of Paiaguas palisadegrass, with an average value of $4.57 \%$. This result may be due to more intense competition among plants for water, light and nutrients when sowing is performed 15 days after millet sowing, which results in low Paiaguas palisadegrass development.

The monocropped Paiaguas palisadegrass silage had lower DM than the monocropped and intercropped pearl millet (Table 3). When evaluating the silage of Brachiaria brizantha cv. Marandu for two regrowth ages, Cezário et al. (2015) found values of 203 and $209 \mathrm{~g} \mathrm{~kg}$ of DM at 35 and 70 days, respectively, no differences were observed regarding the chemical composition and fermentation parameters. In the present study, higher values ( $\left.260 \mathrm{~g} \mathrm{~kg}^{-1} \mathrm{DM}\right)$ than those of Cezário et al. (2015) were found, regardless of the age of regrowth. Zierenberg et al. (2001) reported that tropical grasses have higher water and lower soluble carbohydrate levels and that these factors adversely affect silage quality when considered together. Thus, DM content is a major factor that determines the appropriate point for forage ensiling.

The monocropped pearl millet silage had a DM content of $307.3 \mathrm{~g} \mathrm{~kg}^{-1}$. However, Costa et al. (2012) obtained a lower mean DM content of 274.3 $\mathrm{g} \mathrm{kg}^{-1}$ when evaluating silages of pearl millet genotypes ensiled for 65 days. Normally, silages have lower DM, low concentrations of soluble sugars, and high buffering capacity at the optimal time of cutting, which may lead to undesirable fermentations and large losses (MCDONALD et al., 1991).

Pearl millet intercropped with Paiaguas palisadegrass contributed to greater DM levels in the silages. Thus, intercropping pearl millet could be an effective option because it minimizes problems related to the fermentation of grass-only silages, which have high water contents at the time of cutting.

The results demonstrated that the Paiaguas palisadegrass silage had a higher $\mathrm{pH}$ relative to the monocropped and intercropped pearl millet. This result might have occurred because of the lower soluble carbohydrate content, lower DM, and higher buffering capacity of the monocropped Paiaguas palisadegrass. Usually, the higher $\mathrm{pH}$ value is mainly caused by an increase in buffering capacity that results from proteolysis, which releases ammonia and hinders any decrease in $\mathrm{pH}$ (MCDONALD et al., 1991).

The $\mathrm{pH}$ of the Paiaguas palisadegrass silage ( $\mathrm{pH}$ 4.45) could indicate undesirable fermentation, which is mainly caused by Clostridium bacteria, whose growth is favored in silages with low DM contents and classified as medium quality (McDonald et al., 1991). However, some studies (e.g., TOMICH et al., 2003) report that $\mathrm{pH}$ values between 3.8 and 4.2 are considered adequate for well-conserved silages because restriction of proteolytic plant enzymes and enterobacteria and clostridia occur in this range. In line with previous studies, the pearl millet silage intercropped under different forage systems (row, inter-row, oversown) showed $\mathrm{pH}$ values within the optimal range.

Tropical grass silages become stable at higher $\mathrm{pH}$ values, normally above 4.20 (JOBIM et al., 2007; BERNARDES et al., 2009; RIGUEIRA et al., 2013). The data from this study correspond with the above-mentioned results. However, $\mathrm{pH}$ alone cannot be regarded as a safe criterion for evaluating silages because its inhibitory effects on bacteria and plant enzymes depend on the rate of ionic concentration decline and on the moisture level of the medium. 
Table 3. Dry matter and fermentation characteristics of the silages from different forage system.

\begin{tabular}{lccccc}
\hline Forage system & $\begin{array}{c}\mathbf{D M} \\
\left(\mathrm{g} \mathrm{kg}^{-1}\right)\end{array}$ & $\mathbf{p H}$ & $\begin{array}{c}\mathbf{N}-\mathbf{N H}_{\mathbf{3}} \\
\left(\mathrm{g} \mathrm{kg}^{-1} \mathrm{~N}\right)\end{array}$ & $\mathbf{T A}$ & $\begin{array}{c}\text { BC } \\
\left(\text { Emg } 100 \mathrm{~g}^{-1}\right. \\
\mathrm{DM})\end{array}$ \\
\hline Monocropped pearl millet & $307.3 \mathrm{ab}$ & $3.75 \mathrm{~b}$ & $19.5 \mathrm{~b}$ & $22.42 \mathrm{a}$ & $31.60 \mathrm{~b}$ \\
Monocropped Paiaguas & $273.6 \mathrm{c}$ & $4.45 \mathrm{a}$ & $49.4 \mathrm{a}$ & $17.30 \mathrm{~b}$ & $43.65 \mathrm{a}$ \\
Row pearl millet x Paiaguas & $307.6 \mathrm{ab}$ & $3.90 \mathrm{~b}$ & $25.0 \mathrm{~b}$ & $21.65 \mathrm{a}$ & $34.77 \mathrm{~b}$ \\
Inter-row pearl millet x Paiaguas & $328.1 \mathrm{a}$ & $3.90 \mathrm{~b}$ & $24.2 \mathrm{~b}$ & $21.40 \mathrm{a}$ & $35.57 \mathrm{~b}$ \\
Oversown pearl millet x Paiaguas & $303.1 \mathrm{ab}$ & $3.87 \mathrm{~b}$ & $29.8 \mathrm{~b}$ & $20.45 \mathrm{a}$ & $33.80 \mathrm{~b}$ \\
CV $(\%)$ & 4.66 & 3.20 & 16.94 & 8.15 & 10.77 \\
\hline
\end{tabular}

Means followed by different letters differ according to Tukey's test at a probability level of $5 \%$; DM: dry matter; $\mathrm{N}-\mathrm{NH}_{3} / \mathrm{TN}$ : ammoniacal nitrogen; TA: titratable acidity; BC: buffering capacity.

The highest $\mathrm{N}-\mathrm{NH}_{3}$ level was found in the monocropped Paiaguas palisadegrass silage. According to Leonel et al. (2009), grass silage presents the highest $\mathrm{N}-\mathrm{NH}_{3}$ levels, most likely due to the lower readily fermentable carbohydrate level, lower DM, and higher buffering capacity in the perennial forage grasses. These features allow for the development of proteolytic microorganisms and, consequently, the occurrence of higher proteolysis. According to Henderson (1993), the main factors that determine the extent of protein degradation in the silage material are the DM content, the presence of oxygen, $\mathrm{pH}$ and temperature.

Intercropping pearl millet with Paiaguas palisadegrass was helpful for reducing the $\mathrm{N}-\mathrm{NH}_{3}$ level of the silages due to the high soluble sugar contents of the pearl millet, which were readily available for fermentation by lactic acid-producing bacteria. Therefore, these results indicate the importance of a crop-livestock integration system because lower $\mathrm{N}-\mathrm{NH}_{3}$ levels correspond with higher silage quality. Thus, all of the evaluated silages can be considered high quality because the $\mathrm{N}-\mathrm{NH}_{3}$ content did not exceed 110-120 $\mathrm{g} \mathrm{kg}^{-1}$, the characteristic value of well-conserved silages (VAN SOEST, 1994).

The $\mathrm{N}-\mathrm{NH}_{3}$ results of this study were higher than those found by Amaral et al. (2008). These authors assessed the quality and the nutritional value of silage from three varieties of pearl millet, with values of $12.4,13.8$, and $12.1 \mathrm{~g} \mathrm{~kg}^{-1} \mathrm{~N}$ for the BRS $1501, \mathrm{BN} 1$, and common genotypes, respectively.

The titratable acidity (Table 3 ) is inversely proportional to the $\mathrm{pH}$ of the silage material, a fact that was observed in the present study. The lowest TA value was obtained in the monocropped Paiaguas palisadegrass silage, potentially because this silage presents a higher $\mathrm{pH}$. These results correspond with previous studies that have also indicated this intense relationship (Andrade et al., 2012; Epifanio et al., 2014; Perim et al., 2014). Silva and Queiroz (2002) reported that titratable acidity indicates the general aspect of the fermentation quality of the silage material, which influences the taste, smell, color and stability because it is directly related to the organic acids that determine the $\mathrm{pH}$, especially lactic acid.

Regarding the buffering capacity, only the Paiaguas palisadegrass silage differed $(\mathrm{P}<0.05)$ from the other forage systems (Table 3 ) and had higher values, which shows that the proportion of pearl millet in the silage helped reduce the buffering capacity. Similar results were obtained by Perim et al. (2014), who evaluated Piata palisadegrass silage and observed reductions in the buffering capacity reduction after adding pearl millet bran at ensiling.

The buffering capacity is characterized by the resistance of the forage mass to decreasing $\mathrm{pH}$. The $\mathrm{pH}$ reduction rate depends on the plant $\mathrm{CP}$ level, inorganic ion concentrations (calcium, potassium and sodium), and the combinations of organic acids and salts (JOBIM et al., 2007). Accordingly, McDonald et al. (1991) reported that ensiled materials should not have a high buffering capacity, so as to preserve the nutrient contents of the silage as much possible.

Several organic acids are produced during silage fermentation (lactic, acetic, butyric, isobutyric, propionic, valeric, isovaleric, succinic, and formic acids) (MCDONALD et al., 1991). However, to evaluate the fermentation quality, the most commonly used acids are lactic, butyric, acetic and propionic.

The results presented in Table 4 show that the monocropped silage treatments had significantly different lactic acid concentrations $(\mathrm{P}<0.05)$; however, the highest lactic acid concentrations were obtained in the pearl millet silage. An increase of $77.82 \%$ occurred in the concentration of lactic acid in the monocropped pearl millet relative to the monocropped Paiaguas palisadegrass silage. This result highlights the importance of intercropping pearl millet with Paiaguas palisadegrass on the production of lactic acid. Lactic acid plays an 
important role in fermentation because it presents a higher dissociation constant relative to the remaining acids (MOISIO; HEIKONEM, 1994).

Based on the classification criteria established by Roth and Undersander (1995), silages with lactic acid values of 40 to $60 \mathrm{~g} \mathrm{~kg}^{-1}$ of DM are considered good quality. In this study, the values determined in pearl millet silage monocropped and intercropped in different forage systems showed lactic acid concentrations varying from 38.0 to 47.3 $\mathrm{g} \mathrm{kg}^{-1}$ of DM, which allowed us to classify them as good quality.

Therefore, the lactic acid values determined in this study were higher relative to those of acetic acid, which corresponds with the statements of Kung and Shaver (2002). These authors explain that lactic acid should be the main acid in good-quality silage and that the lactic acid content should be higher than the remaining acids (acetic, propionic, butyric) because although all acids produced during fermentation contribute to reducing the silage $\mathrm{pH}$, lactic acid plays a key role in this process because it has a higher dissociation constant than the other acids (MOISIO; HEIKONEM, 1994).

Tremblay et al. (2014) added that wellfermented silage is characterized by reductions in $\mathrm{pH}$ and $\mathrm{NH}_{3}-\mathrm{N}$ and is inversely proportional to the lactic acid concentration, which results in higher values.

The acetic acid concentration was higher $(\mathrm{P}<0.05)$ in the monocropped Paiaguas palisadegrass silages and in the silages from the pearl millet intercropped within the rows with Paiaguas palisadegrass (Table 4). According to McDonald et al. (1991), high acetic acid production indicates enterobacteria action during the early stages of fermentation, and acetic acid directly competes with lactic acid bacteria for nutrients, which results in lower DM contents and energy. Thus, well-conserved silage must present a low acetic acid concentration, which can also be used as a parameter for determining the quality of silage fermentation (TOMICH et al., 2003).
Equilibrium in the acetic acid concentrations of the silages was observed when the pearl millet was used in the different forage systems, which reduced the levels from $11.3 \mathrm{~g} \mathrm{~kg}^{-1}$ for the monocropped Paiaguas palisadegrass to a mean value of $8.3 \mathrm{~g} \mathrm{~kg}^{-1}$ of DM in the intercropping systems. These results support using a croplivestock integrated system to improve silage fermentation parameters because lower acetic acid levels correspond with higher silage fermentation quality.

However, the acetic acid concentrations of all of the analyzed silages were less than $20 \mathrm{~g} \mathrm{~kg}^{-1}$ of DM, which indicates very good quality according to criteria established by Roth and Undersander (1995). The responses of animals to silage depend on the silage fermentation pattern, which significantly influences the chemical composition, ingestion, and digestibility of the forage (JOBIM et al., 2007).

The highest concentration of propionic acid was found in the monocropped Paiaguas palisadegrass silage, potentially due to the lower $\mathrm{DM}$ content and higher $\mathrm{pH}$ of the Paiaguas palisadegrass silage, which would enable the development of Clostridium bacteria (McDonald, 1991). The silages achieved propionic acid concentrations from 1.8 to $2.8 \mathrm{~g} \mathrm{~kg}^{-1}$. As described by Roth and Undersander (1995), the presence of propionic acid above the established limit indicates the degradation of lactic acid by butyric acid bacteria. However, this degradation is not considered in this situation because the propionic acid concentrations were below $5.0 \mathrm{~g} \mathrm{~kg}^{-1}$ of DM.

The butyric acid concentrations did not differ $(\mathrm{P}>0.05)$ across the different forage systems, with values ranging from 0.1 to $0.3 \mathrm{~g} \mathrm{~kg}^{-1}$ (classified as very good quality $\left(<1.0 \mathrm{~g} \mathrm{~kg}^{-1}\right.$ of DM butyric acid) according to Roth and Undersander (1995). The butyric acid concentrations obtained in this study were similar to those found by Guimarães Júnior et al. (2005), who evaluated silages obtained from three pearl millet genotypes (CMS-1, BRS1501, and BN-2).

Table 4. Organic acid concentrations $\left(\mathrm{g} \mathrm{kg}^{-1} \mathrm{DM}\right)$ of silage from different forage system.

\begin{tabular}{lcccc}
\hline Forage system & Lactic & Acetic & Propionic & Butyric \\
\hline Monocropped pearl millet & $47.3 \mathrm{a}$ & $6.7 \mathrm{~b}$ & $1.8 \mathrm{~b}$ & $0.1 \mathrm{a}$ \\
Monocropped Paiaguas & $26.6 \mathrm{~b}$ & $11.3 \mathrm{a}$ & $2.8 \mathrm{a}$ & $0.3 \mathrm{a}$ \\
Row pearl millet x Paiaguas & $38.0 \mathrm{ab}$ & $9.0 \mathrm{ab}$ & $2.2 \mathrm{~b}$ & $0.2 \mathrm{a}$ \\
Inter-row pearl millet x Paiaguas & $40.7 \mathrm{ab}$ & $8.2 \mathrm{~b}$ & $2.0 \mathrm{~b}$ & $0.2 \mathrm{a}$ \\
Oversown pearl millet x Paiaguas & $42.1 \mathrm{ab}$ & $7.9 \mathrm{~b}$ & $2.0 \mathrm{~b}$ & $0.2 \mathrm{a}$ \\
CV $(\%)$ & 20.90 & 14.02 & 10.62 & 27.92 \\
\hline
\end{tabular}

Means followed by different letters differ according to tukey's test at the 5\% probability level. 
Regarding the $\mathrm{CP}$ content, the pearl millet monocropped and intercropped with Paiaguas palisadegrass silages had the highest values $(\mathrm{P}>0.05)$ (Table 5). Thus, the $\mathrm{CP}$ content in the monocropped pearl millet silage was $34.39 \%$ higher than that of the monocropped Paiaguas palisadegrass. Costa et al. (2011b) found mean CP values of 121.8 and $132.0 \mathrm{~g} \mathrm{~kg}^{-1}$ for the pearl millet silage genotypes ADR 500 and ADR 7010, respectively. These values were similar to those obtained in this study for the monocropped pearl millet silage.

In all forage systems, the silages showed $\mathrm{CP}$ contents with greater than $70 \mathrm{~g} \mathrm{~kg}^{-1}$ of DM, which is the minimum value necessary for avoiding microbial growth compromises in the rumen and for promoting efficient use of the fiber carbohydrates from the basal forage (Lazzarini et al., 2009).
The largest EE content was obtained in monocropped pearl millet. The consortium millet Paiaguas palisadegrass in all forms of sowing increased the EE content in silage (Table 5). This result is relevant because tropical forages are low in fat.

Significant differences $(\mathrm{P}<0.05)$ were observed between the mineral material contents of the monocropped systems, and the monocropped Paiaguas palisadegrass silage had the highest mineral material value (Table 5). According De Paula et al. (2016), the largest concentrations of minerals for forage may arise from the age of the plant, as plants in an initial development stage have higher mineral contents; another factor would be the genetic capacity of the plant to accumulate minerals.

Table 5. Chemical composition and in vitro dry matter digestibility of the silages from different forage system

\begin{tabular}{lccccccc}
\multicolumn{1}{c}{$\left(\mathrm{g} \mathrm{kg}^{-1} \mathrm{DM}\right)}$. & $\mathbf{C P}$ & $\mathbf{E E}$ & $\mathbf{M M}$ & TDN & NDF & ADF & IVDM \\
\hline Forage system & $148.1 \mathrm{a}$ & $47.3 \mathrm{a}$ & $16.7 \mathrm{~b}$ & $689.0 \mathrm{a}$ & $573.2 \mathrm{c}$ & $337.1 \mathrm{~b}$ & $683.5 \mathrm{a}$ \\
\hline $\begin{array}{l}\text { Monocropped pearl } \\
\text { millet }\end{array}$ & & & & & & & \\
Monocropped Paiaguas & $110.2 \mathrm{~b}$ & $20.7 \mathrm{c}$ & $31.6 \mathrm{a}$ & $597.5 \mathrm{c}$ & $681.7 \mathrm{a}$ & $420.4 \mathrm{a}$ & $540.3 \mathrm{~b}$ \\
$\begin{array}{l}\text { Row pearl millet x } \\
\text { Paiaguas }\end{array}$ & $127.7 \mathrm{ab}$ & $31.9 \mathrm{~b}$ & $22.0 \mathrm{ab}$ & $642.9 \mathrm{~b}$ & $607.9 \mathrm{bc}$ & $388.5 \mathrm{ab}$ & $656.1 \mathrm{a}$ \\
$\begin{array}{l}\text { Inter-row pearl millet x } \\
\text { Paiaguas }\end{array}$ & $119.7 \mathrm{~b}$ & $32.9 \mathrm{~b}$ & $22.2 \mathrm{ab}$ & $663.9 \mathrm{ab}$ & $635.2 \mathrm{~b}$ & $362.9 \mathrm{ab}$ & $640.7 \mathrm{a}$ \\
$\begin{array}{l}\text { Oversown pearl millet x } \\
\text { Paiaguas }\end{array}$ & $123.6 \mathrm{~b}$ & $39.2 \mathrm{~b}$ & $21.9 \mathrm{ab}$ & $669.8 \mathrm{ab}$ & $602.7 \mathrm{bc}$ & $398.4 \mathrm{ab}$ & $665.0 \mathrm{a}$ \\
CV (\%) & 8.22 & 12.64 & 21.87 & 4.08 & 4.44 & 7.50 & 6.16 \\
\hline
\end{tabular}

Means followed by different letters differ according to Tukey's test at the 5\% probability level; CP: crude protein; EE: ether extract; MM: mineral material; TDN: total digestible nutrient; NDF: neutral detergent fiber; ADF: acid detergent fiber; IVDMD: in vitro dry matter digestibility.

When silage presents inadequate fermentation, the possibility of organic matter $(\mathrm{OM})$ losses increases, which increases the proportion of MM (ASHBELL, 1995). Thus, the highest $\mathrm{pH}$, buffering capacity, and $\mathrm{N}-\mathrm{NH}_{3}$ values and the lowest TA value were observed in the monocropped Paiaguas palisadegrass silage.

By evaluating the TDN content, the monocropped Paiaguas palisadegrass silage had the lowest values, which were different from those of other forage systems $(\mathrm{P}<0.05) \quad($ Table 5). Intercropping pearl millet with Paiaguas palisadegrass contributed to increases in the TDN levels in all forms of sowing and emphasized the importance of using intercropping systems to obtain satisfactory results. These results most likely resulted from two factors: higher TDN levels in the pearl millet compared with the Paiaguas palisadegrass (Table 1). The intercropping systems allow for the establishment of livestock production systems that meet new sustainability standards by using a crop-livestock integration system. Positive results from the addition of pearl millet to tropical grasses silage were also observed when considering Marandu palisadegrass, Piata palisadegrass, Xaraes palisadegrass (COSTA et al., 2012) and Piata palisadegrass silage (PERIM et al., 2014).

The NDF contents were influenced $(\mathrm{P}<0.05)$ by the forage systems (Table 5). The NDF level of the pearl millet silage was $15.92 \%$ lower than that of the Paiaguas palisadegrass silage. Again, these results demonstrate the advantages of producing silage in intercropping systems because intercropping pearl millet with Paiaguas palisadegrass in all forms of sowing can help reduce NDF and lead to a fiber dilution effect due to the lower NDF content of the pearl millet crop. These results agree with those of Leonel et al. (2009), who 
found that monocropped Marandu palisadegrass silage showed higher NDF than other forage systems.

The NDF contents found in this study for the monocropped and intercropped pearl millet silage indicate no reductions in silage intake because the NDF values were similar to those recommended in the literature. For example, according to Lima et al. (2002), the positive correlation with forage intake was greater when the NDF was closer to $600 \mathrm{~g} \mathrm{~kg}^{-1}$ of DM.

Additionally, according to Oliveira et al. (2011) sources with the same NDF content may have different responses, in the same way as sources with higher NDF do not necessarily imply more negative responses in intake and digestion. In this way, factors such as the chemical composition of the NDF and the type of lignin determine the physicochemical interactions with the other components, specifically dimension of fractions potentially degradable (NDFpd) and undegradable (NDFi).

The quantities and qualities of the fibrous fractions in roughage must be observed to predict their nutritional capacity. According to Van Soest (1994), high levels of these constituents interfere with animal nutrition because they affect the DM intake and digestibility of the silages. In this context, regarding the ADF levels, only the monocropped pearl millet differed $(\mathrm{P}<0.05)$ from the monocropped Paiaguas palisadegrass, and the monocropped pearl millet had the lowest value. In addition, Costa et al. (2012) observed lower ADF levels for pearl millet silage than for grass silages of the Brachiaria genus.

These results further emphasize the importance of intercropping pearl millet with Paiaguas palisadegrass to increase the IVDMD of silages (Table 5). These results are due to the higher $\mathrm{CP}$ and lower fibrous fraction levels of the pearl millet (Table 1), which favor better feed digestibility. This observation agrees with the study of Jayme et al. (2007), who states that silages with higher NDF and ADF levels have reduced IVDMD values.

In recent years, pearl millet has gained prominence, mainly owing to the availability of new early genotypes with high nutritional values and productive potentials due to genetic improvements (COSTA et al., 2012). Thus, this crop is no longer considered a simple species but, rather, has economic value for producing quality forage and silage. The IVDMD values in the monocropped and intercropped pearl millet silage are similar to those obtained by Guimarães et al. (2014), who ensiled pearl millet genotypes during the same phenological stage (65 days) of this study and found a mean IVDMD value of $652.7 \mathrm{~g} \mathrm{~kg}^{-1}$ for the silage.

The nutritional quality of the intercropped silages may be considered satisfactory for maintaining nutrition and could result in moderate weight gains during the critical dry season. During this season, a seasonal decrease in forage production generally occurs. In addition to providing nutritional benefits, obtaining silage from intercropping systems is also advantageous because it results in a higher total forage yield (Table 2).

\section{CONCLUSION}

Pearl millet monocropped and intercropped with Paiaguas palisadegrass silage exhibited better fermentative and bromatological characteristics than silage obtained from monocropping Paiaguas palisadegrass. Therefore, using these intercropped forages for silage ensures proper silage fermentation and nutritional quality. Thus, creating silage from intercropped forages provides an interesting supplemental roughage option that can be used during the offseason for animal feeding.

RESUMO: Com a chegada de novos genótipos precoces e de alto valor nutritivo e potencial produtivo, o milheto vem ganhando destaque nos últimos anos para a produção de silagens, com menor custo de produção. Com isso, o consórcio do milheto com forrageiras tropicais, pode aumentar a produção da silagem, proporcionando maior quantidade de alimento para ser utilizado na entressafra, onde se tem baixa disponibilidade de forragem. Sendo assim, objetivou-se avaliar a produção de massa seca, características fermentativas e a composição químico-bromatológica da silagem de milheto e capim-paiaguás em monocultivo e consorciado em diferentes sistemas forrageiros, na safrinha. $\mathrm{O}$ delineamento experimental utilizado foi em blocos casualizados, com quatro repetições. Os tratamentos foram constituídos da silagem dos seguintes sistemas forrageiros: milheto em monocultivo, capim-paiaguás em monocultivo, milheto consorciado com capim-paiaguás na linha, milheto consorciado com capim-paiaguás na entrelinha e milheto consorciado com capimpaiaguás na sobressemeadura, totalizando 20 silos experimentais. O consórcio do milheto com capim-paiaguás contribuiu para elevar os teores de matéria seca das silagens, exceto, no sistema utilizando a sobressemeadura. As silagens de milheto em monocultivo e consorciadas com capim-paiaguás apresentaram reduções nos valores de pH e nitrogênio amoniacal, bem como, favorecem a fermentação lática. As silagens de milheto em monocultivo e consorciadas apresentaram melhores características fermentativas e bromatológicas quando comparadas com silagem de capim-paiaguás em monocultivo. 
Portanto, silagens produzidas nos sistemas consorciados constitui interessante opção de volumosos suplementar para alimentação dos animais no período de entressafra.

PALAVRAS-CHAVE: Brachiaria brizantha cv. BRS Paiaguás. Características fermentativas. Composição bromatológicas. Pennisetum glaucum (L.) R. Br.

\section{REFERENCES}

AMARAL, P. N. C.; EVANGELISTA, A. R.; SALVADOR, F. M.; PINTO, J. C. Qualidade e valor nutritivo da silagem de três cultivares de milheto. Ciência e Agrotecnologia, Lavras, v. 32, n. 2, p. 611-617, 2008. http://dx.doi.org/101590/S1413-70542008000200041

ASHBELL, G. Basic principles of preservation of forage, by-products and residues as silage or hay. Bet Dagan: Agricultural Research Organization, The Volcani Center. p. 58, 1995.

ANDRADE, A. P.; QUADROS, D. G. de; BEZERRA, A. R. G.; ALMEIDA, J. A. R.; SILVA, P. H. S.; ARAUJO, J. A. M. Aspectos qualitativos da silagem de capim-elefante com fubá de milho e casca de soja. Semina: Ciências Agrárias, Londrina, v. 33, n. 3, p. 1209-1218, 2012. http://dx.doi.org/10.5433/16790359.2012v33n3p1209

BERNARDES, T. F.; REIS, R. A.; AMARAL, R. C. Chemical and microbiological changes and aerobic stability of marandu grass silages after silo opening. Revista Brasileira de Zootecnia, Viçosa, v. 38, n. 1, p. 18, 2009. http://dx.doi.org/10.1590/S1516-35982009000100001

CEZÁRIO, A. S.; RIBEIRO, K. G.; SANTOS, S. A.; DE CAMPOS VALADARES FILHO, S.; PEREIRA, O. G. Marandu harvested at two regrowth ages: microbial inoculant responses in silage fermentation, ruminant digestion and beef cattle performance. Animal Feed Science and Technology, v. 208, p. 33-43, 2015. http://dx.doi.org/10.1016/j.anifeedsci.2015.06.025

CHANDLER, P. Energy prediction of feeds by forage testing explorer. Feedstuffs, v. 62, p. 12, 1990.

COSTA, K. A. P.; ASSIS, R. L.; PERIM, R. C.; GUIMARÃES, K. C.; PALUDO, A.; PRIVADO, C. J. T.; VIEIRA, T. P. Quality and nutritional value of pearl millet genotypes silage produced with and without inoculants. Revista Brasileira de Saúde e Produção Animal, Salvador, v. 12, n. 2, p. 286-295, 2011 b.

COSTA, K. A. P.; GUERRA FILHO, I. A.; ASSIS, R. L.; GUIMARÃES, K. C.; CRUVINEL, W. S.; EPIFÂNIO, P. S.; GOUVEIA, R. R. Silage quality of pearl millet cultivars produced in different cutting ages. Semina: Ciências Agrárias, Londrina, v. 33, n. 3, p. 1189-1198, 2012. http://dx.doi.org/10.5433/16790359.2012v33n3p1189

COSTA, K. A. P.; ASSIS, R. L.; GUIMARÃES, K. C.; SEVERIANO, E. C.; ASSIS NETO, J. M.; CRUNIVEL, W. S.; GARCIA J. F.; SANTOS, N. F. Silage quality of Brachiaria brizantha cultivars ensiled with different levels of millet meal. Arquivo Brasileiro de Medicina Veterinária e Zootecnia, Belo Horizonte, v. 63, n. 1, p. 188-195, 2011a. http://dx.doi.org/10.1590/S0102-09352011000100028

DE PAULA, F. L. M.; MENEZES, L. F. G.; PARIS, W.; RONSANI, R.; HOPPEN, S. M.; CIESCA, J. Silage production and the chemical composition of corn and Grass-tanzania intercropping. Semina: Ciências Agrárias, Londrina, v. 37, n. 3, p. 1607-1616, 2016. http://dx.doi.org/10.5433/1679-0359.2016v37n3p1607

DETMAnN, E.; SOUZA, M. A.; VALADARES FILHO, S. C. Métodos para Análise de Alimentos. Instituto Nacional de Ciência e Tecnologia de Ciência Animal. Visconde do Rio Branco: Suprema, p. 214, 2012.

EMBRAPA GADO DE CORTE- Empresa Brasileira de Pesquisa Agropecuária. BRS Paiaguás, uma nova força para a pecuária. Informativo Paiaguás, 2014. 
EPIFANIO, P. S.; COSTA, K. A. P.; SEVERIANO, E. C.; CRUVINEL, W. S.; BENTO, J. C.; PERIM, R. C. Fermentative and bromatological characteristics of Piata palisadegrass ensiled with levels of meals from biodiesel industry. Semina: Ciências Agrárias, Londrina, v. 35, n. 1, p. 491-504, 2014. http://dx.doi.org/10.5433/1679-0359.2014v35n1p491

FERREIRA, D. F. Sisvar: a computer statistical analysis system. Ciência e Agrotecnologia, Lavras, v. 35, n. 6, p. 1039-1042, 2011.

GUIMARÃES, K. C.; COSTA, K. A. P.; PALUDO, A.; SANTOS, N. F.; ROSSI, R. M.; CRUVINEL, W. S. Protein fraction, degradability and digestibility of pearl millet silage at different cutting ages. Acta

Scientiarum. Animal Sciences, Maringá, v. 36, n. 1, p. 33-39, 2014

http://dx.doi.org/10.4025/actascianimsci.v36i1.21415

GUIMARÃES JUNIOR, R.; GONÇALVES, L. C.; SANTOS, J. A.; RODRIGUEZ, N. M.; BORGES, A. L. C. C.; BORGES, I. R.; SALIBA, E. O. S.; JAYME, D. G.; PIRES, D. A. A. Carboidratos solúveis, digestibilidade "in vitro" da matéria seca e ácidos orgânicos das silagens de três genótipos de milheto [Pennisetum glaucum (1). r. br.] em diferentes períodos de fermentação. Revista Brasileira de Milho e Sorgo, Sete Lagoas, v. 4, n. 1, p. 95-103, 2005. https://doi.org/10.18512/1980-6477/rbms.v4n1p95-103

GUIMARAES, JR. R.; GONÇALVES, L. C.; MAURÍCIO, R. M.; PEREIRA, L. G. R; TOMICH, T. R.; PIRES, D. A. A.; JAYME, D. G.; SOUSA, L. F. Cinética de fermentação ruminal de silagens de milheto. Arquivo Brasileiro de Medicina Veterinária de Zootecnia, Belo Horizonte, v. 60, n. 5, p. 1174-1180, 2008. http://dx.doi.org/http://dx.doi.org/10.1590/S0102-09352008000500020

HENDERSON, N. Silage additives. Animal Feed Science Technology, New York, v. 45, n. 1, p. 35-56, 1993. http://dx.doi.org/10.1016/0377-8401(93)90070-Z

JAYME, D. G.; GONÇALVES, L. C.; RODRIGUES, J. A. S.; PIRES, D. A. A.; GUIMARÃES JÚNIOR, R. N. M.; BORGES, I; BORGES, A. L. C. C.; SALIBA, E. O. S.; JAYME, C. G. Qualidade das silagens de genótipos de girassol (Helianthus annuus) confeiteiros e produtores de óleo. Arquivo Brasileiro de Medicina Veterinária e Zootecnia, Belo Horizonte, v. 59, n. 5, p. 1287-1293, 2007. http://dx.doi.org/10.1590/S010209352007000500028

JOBIM, C. C.; NUSSIO, L. G.; REIS, R. A.; SCHMIDT, P. Avanços metodológicos na avaliação da qualidade da forragem conservada. Revista Brasileira de Zootecnia, Viçosas, v. 36, p. 101-119, 2007. (supl. Especial). http://dx.doi.org/10.1590/S1516-35982007001000013

KUNG, JR., L.; SHAVER, R. Interpretation and Use of Silage Fermentation Analyses Reports. Focus on Forage, Madison, v. 3, p. 1-5, 2002.

KUNG, JR., L. Use of additives in silage fermentation. In: Direct-fed Microbial, Enzyme and Forage Additive Compendium, Minnetonka, p. 37-42, 1996.

LAZZARINI, I.; DETMANN, E.; SAMPAIO, C. B.; PAULINO, M. F.; VALADARES FILHO, S. C.; SOUZA, M. A.; OLIVEIRA, F. A. Intake and digestibility in cattle fed low-quality tropical forage and supplemented with nitrogenous compounds. Revista Brasileira de Zootecnia, Viçosas, v. 38, p. 2021- 2030, 2009. http://dx.doi.org/10.1590/S1516-35982009001000024

LEONEL, F. P. L.; PEREIRA, J. C.; COSTA, M. G.; MARCO JÚNIOR, P.; DA SILVA, C. J.; LARA, L. A. Consórcio capim-braquiária e milho: comportamento produtivo das culturas e características nutricionais e qualitativas das silagens. Revista Brasileira de Zootecnia, Viçosas, v. 38, n. 1, p. 166-176, 2009.

http://dx.doi.org/10.1590/S1516-35982009000100021 
LIMA; L. G.; NUSSIO; L. G. N.; GONÇALVES, J. R. S.; SIMAS, J. M. C.; PIRES, A. V.; SANTOS, F. A. P. Fontes de amido e proteína para vacas leiteiras em dietas à base de capim-elefante. Scientia Agricola, Piracicaba, v. 59, n. 1, p. 19-27, 2002. http://dx.doi.org/10.1590/S0103-90162002000100002

McDONALD, P.; HENDERSON, A. R.; HERON, S. J. E. The biochemistry of silage. 2.ed. Marlow: Chalcombe Pub, p. 340, 1991.

MOISIO, T.; HEIKONEM, M. Latic acid fermentation on silage preserved with formic acid. Animal Feed Science and Technology, Amsterdam, v. 47, n. 1, p. 107-124, 1994. http://dx.doi.org/10.1016/03778401(94)90164-3

OLIVEIRA, A. S.; DETMANN, E.; DE SOUZA CAMPOS, J. M; PINA, D. S.; SOUZA, S. M.; COSTA, M. G. Meta-análise do impacto da fibra em detergente neutro sobre o consumo, a digestibilidade e o desempenho de vacas leiteiras em lactação. Revista Brasileira de Zootecnia, Viçosas, v. 40, n. 7, p. 1587-1595, 2011. http://dx.doi.org/10.1590/S1516-35982011000700026

PERIM, R. C.; COSTA, K. A. P.; EPIFANIO, P. S.; SOUZA, W. F.; FRANCISCHINI, R.; TEIXEIRA, D. A. A.; CARVALHO, W. G.; SANTOS JR., D. R. Fermentative and bromatological characteristics of Piata Palisadegrass ensiled with energetic brans. American Journal of Plant Sciences, v. 5, p. 942-954, 2014. http://dx.doi.org/10.4236/ajps.2014.57107

PLAYNE, M. J. AND MCDONALD, P. The buffering constituents of herbage and of silage. Journal Science Food Agriculture, v. 17, p. 264-268, 1966. https://doi.org/10.1002/jsfa.2740170609

ROTH, G.; UNDERSANDER, D. Silage additives. In: Corn Silage Production Management and Feeding. Madison: Madison American Society of Agronomy, p. 27-29, 1995.

SILVA, D. J; QUEIROZ, A. C. Análise de alimentos: métodos químicos e biológicos. Viçosa- MG: UFV, p. 235, 2002.

TILLEY J; M; A.; TERRY R; A. A two-stage technique of the "in vitro" digestion of forage crop. Journal of the British Grassland Society, Oxford, v. 18, n. 2, p. 104-111, 1963. TREMBLAY, G. F., MORIN, C.; BÉLANGER, G. BERTRAND, A., CASTONGUAY, Y.; BERTHIAUME, R.; ALLARD, G. Silage Fermentation of PM- and AM-Cut Alfalfa Wilted in Wide and Narrow Swaths. Crop Science, Madison, v. 54, p. 439-452, 2014.

TOMICH, T.; PEREIRA, L. G. R.; GONÇALVES, L. C.; TOMICH, R. G. P.; BORGES, I. Características químicas para avaliação do processo fermentativo de silagem: uma proposta para qualificação da fermentação. Corumbá: Embrapa Pantanal, 2003. 20 p. (Embrapa Pantanal. Documento, 57).

VAN SOEST, P.J. Nutritional ecology of the ruminant. 2 ed. Ithaca: Cornell, p. 476, 1994.

ZIERENBERG, B.; FRIEDEL, K.; GLATZLE, A. CHUDY, A. Assessment of Ensilability of six tropical grasses using three different approaches. Proceedings of the XIX In: International Grassland Congress, Sao Pedro, 2001, Proceedings. São Pedro: FEALQ, p. 786-788, 2001. 